\title{
Territorial Politics and the Reach of the State: UNEVENNESS BY DESIGN*
}

\author{
Política territorial y el alcance del Estado: Irregularidad por diseño
}

\section{CATHERINE BOONE}

University of Texas at Austin

\begin{abstract}
Guillermo O'Donnell drew attention to "brown spots" in Latin America's political topography, which he defined as peripheral regions where the presence of the republican state is attenuated and more arbitrary forms of power hold sway. Similarly uneven projections of state authority are visible across sub-Saharan Africa. This paper reviews three ways of explaining such unevenness in the state's reach: (a.) a geographic, economic, and demographic determinism perspective, (b.) a historical-sociological perspective, and (c.) a political perspective centered on strategic bargaining between social actors and state actors. We propose that unevenness in state quality is often an artifact of state-building, rather than evidence of state failure. An analysis of statebuilding in modern Africa, focusing on Côte d'Ivoire, explores some of these dynamics.
\end{abstract}

Key words: State-building, Africa, Political Economy, Côte d'Ivoire, Territory.

\begin{abstract}
RESUMEN
Guillermo O'Donnell prestó atención a las "zonas marrones" en la topografía política de América Latina. O'Donnell definió a estas zonas como regiones periféricas donde la presencia del estado de derecho es atenuada y donde imperan formas de poder arbitrarias. De igual modo, las proyecciones irregulares de la autoridad estatal son visibles a través del África sub-sahariana. Este trabajo revisa tres formas de explicar dicha irregularidad en el alcance del Estado: a) una perspectiva determinista geográfica, económica y demográfica; $b$ ) una perspectiva histórico-sociológica; c) una perspectiva política centrada en la negociación estratégica entre actores sociales y actores estatales. Proponemos que la irregularidad en la calidad del Estado, en lugar de ser evidencia de un estado fallido es a menudo un artefacto de construcción del Estado. Se exploran estas dinámicas a partir de un análisis de la construcción del Estado en el África moderna.
\end{abstract}

Palabras clave: Construcción del Estado, África, economía política, Costa de Marfil, territorio.

* A version of this paper was prepared for the 2012 annual meetings of the American Political Science Association, New Orleans, Louisiana, 1 September 2012, and I thank discussant Scott Radnitz for his comments. An earlier draft of this version was presented at the conference on The State of Stateness in Latin America in the 21st Century: Concepts and Challenges, held at the Instituto de Ciencia Politica, Universidad Católica de Chile in Santiago de Chile, 29-30 March 2012. I thank the organizers for the invitation to participate and for their feedback. This paper incorporates some material from Boone 2007a, and I thank the African Studies Review for permission to reuse some of the material therein. This article is part of the Millenium Nucleus for the Study of Stateness and Democracy in Latin America, Project NS100014, of the Ministry of Economy and Tourism of Chile. 


\begin{abstract}
"Let us imagine a map of each country in which the areas covered by blue would designate the areas where there is a high degree of state presence (in terms of a set of reasonably effective bureaucracies, and the effectiveness of properly sanctioned legality), both functionally and territorially; the green color indicates [an intermediate case]; and the brown color a very low or nil level on both dimensions.... [The extensive presence of such brown areas] entails the introjection of authoritarianism -understood here as the denial of publicness and of the effective legality of a democratic state and hence, or citizenshipat the very center of political power of these countries".
\end{abstract}

(Guillermo O’Donnell, 1993:1359-1360)

Guillermo O'Donnell drew attention to the existence of "brown spots" in the political topography of Latin American states, which he defined as peripheral regions or districts in which the presence of the republican state is attenuated and more arbitrary forms of power -neofeudal, sultanistic, personalistic, and clientelistic- hold sway. ${ }^{1}$ Similarly uneven projections of republican state authority, citizenship rights, and access to the legal and political institutions of the modern state are visible across most sub-Saharan African countries. Analysts like Mahmood Mamdani (1996) and Issa Shivji (2006) have described the rural areas (where approximately $60-70 \%$ of the sub-Saharan population now resides) as governed under neocustomary or administrative despotism, in contrast to the more open and liberal political orders prevailing in the cities, especially for the middle classes. The character of state authority and the quality of citizenship vary both functionally and territorially (and along class lines), precisely as O'Donnell described.

O'Donnell's 1993 discussion stressed that the "unevenness of stateness" can result from territorially-uneven breakdowns or decay that are caused by prolonged economic crises, or neoliberal restructurings. Yet as his examples of Brazil's Amazonia, highland Peru, and northwest Argentina suggest, "brown spots" are not necessarily the result of any erosion of stateness. Instead, this unevenness may be the result, or effect, of state-building itself.

The implicit counterfactual in many discussions of the uneven reach of the state is what O'Donnell imagines as "blue areas". Blue areas are spatialized (idealized) representations of the fully-integrated republican state, wherein the rules and practices of political authority at the local level mirror the rules and practices that prevail at the national level. Blue areas are regions in fully integrated national economies in which systems of territorial administration are spatially uniform, and standardized law and property rights are projected evenly across the national space.

This ideal does not hold for African countries, and it may not be a reliable point of reference for most countries. As the federal systems studied by E.E. Schattschneider (1960) and Edward Gibson (2008), or in the "multilevel jurisdictions" of Indonesia described by Dik Roth (2003), African states (and most perhaps other states) are characterized by heterogeneity of scale (and scope). In Africa, most rural jurisdictions look like O'Donnell's brown areas. States are marked by a partial disarticulation of most local political arenas from national citizenship regimes, accountability mechanisms, and the rules of political representation that are inscribed in the national constitutions. Mahmood Mamdani is 
correct in arguing that this disarticulation has been a structural feature of virtually all African states, including the apartheid state in South Africa. ${ }^{2}$ A general effect is one that Philip Nord identified in nineteenth century Europe: the uneven and unstable integration of the countryside into the civic life of the nation. ${ }^{3}$

Several of the papers in this collection attempt to address this question of unevenness in the territorial reach of the state (Soifer, Kurtz and Schrank), prioritizing measuring it rather than explaining it. The present study moves in a different although possibly complementary direction, focusing on determinants of uneveness and placing the problem of state reach in larger political and political-economy context, as do the papers by Eaton, Feldmann, and Policzer in this collection. Part I reviews three different (perhaps converging) ways of explaining unevenness in the reach of the state: (a.) a geographic, economic, and demographic determinism perspective, (b.) a historical-sociological perspective, and (c.) a political perspective centered on strategic bargaining between social actors and state actors. Drawing on these perspectives, we propose that heterogeneity (unevenness) of scale and scope is often an artifact of state-building, rather than a sign of the failure thereof. We can call this "unevenness by design".

Part II illustrates some of these dynamics in a consideration of territorially-uneven statebuilding strategies in modern Africa, where the rise of state infrastructural capacity in the 1950-1980 period was followed by a general decline in state capacity in most states starting in the mid-1980s, in an era of economic liberalization and state retrenchment. The discussion points to some of the historical contingencies, territorial strategies, and political logics that have guided state-building (and the erosion of stateness) in this part of the world.

\section{CONCEPTUALIZING UNEVENNESS IN THE REACH OF THE STATE}

\section{a) Geographic and Demographic Perspectives}

Geographers' and economists' work on state-building underscores the fact that projection of central state power through space is costly. This work suggests that rational statebuilders will weigh the costs (and risks) of power-projection against the benefits (and risks) of not doing so. Such an approach predicts that the costs of power projection will outweigh the benefits in (i.) peripheral or difficult-to-access regions of the national territory, (ii.) zones of low population density, and (iii.) where there are few resources for the central state or its principals to exploit. In such areas, states will refrain from investing in the build-up of extensive infrastructural power. Where all three of these conditions hold, and in the absence of a threat to rulers emanating from such a region (such as counterinsurgency in a mountainous or remote locale), central rulers' choice to refrain from power-projection in these zones can be viewed, from a strategic perspective, as a

2 Mamdani (1996) tapped into this when he characterized the African state as "bifurcated" along urban-rural lines.

3 Nord, in Bermeo and Nord (2000), p. xxiii. Nord observes that it is the stable integration of the countryside that seems to create conditions for democratic institutions to take root. 
"rational choice" rather than a failure. New institutional economics would predict that states would pay the transaction costs of government administration only where the returns were positive. In political geography, the basic core-periphery model of the state captures this idea of an positive relationship between density and weight of government and administration, population density, and proximity to "the center" (Herbst, 2000; Alesina and Spolaore, 2003; Demsetz, 1967; Green, 2012).

In colonial Africa, French rulers routinely distinguished between l'Afrique utile, where the building of administrative infrastructure was deemed to be worth their while, and $l^{\prime}$ Afrique inutile, the parts of the continent deemed useless because they produced less than it cost to administer them.

\section{b) Historical and Sociological Perspectives}

The political sociology of Lipset and Rokkan (1967) imagined "the national community" in European states as defined by layered cleavage systems than ran along lines of region (territorial, including rural-urban lines), language, ethnicity, religion. These were traceable, in part, to distinctions and oppositions that emerge in the process of national construction. Extension of the suffrage in the initial phases of nation-building was expected to accentuate contrasts between the countryside and urban centers (p. 12). The class cleavage would emerge clearly only in later phases, when the "two revolutions" -the national and the industrial- were nearly complete. Synergy between the two revolutions promotes and accompanies "the consolidation of the national territory" (p. 13) through the intensifying interaction, communication, and "social mobilization" of urbanization and industrialization. Unification of standardization of administrative infrastructure and law are seen as part of this process; these widen and deepen the reach of the state.

By this logic, the process of building the modern state is uneven and graduated, and propelled forward by underlying sociological and socio-economic transformations -including the building of national economies (integration of land, labor, and capital markets) and urbanization and industrialization. We would expect unevenness in these socioeconomic process to be reflected in uneven state-building (Caramani, 2004; Hechter, 2008). Unevenness in state infrastructural power should mirror strong economic and political localisms. In much of Africa, as in countries like India ${ }^{4}$ and Mexico, the nationalizing effects of industrialization and urbanization are partial and uneven.

State-building itself can promote this nationalizing effects. Central state provision of social services (Chhibber and Kollman, 2005) and unification of the national regulatory apparatus (Skrowneck, 1982; EE Schattschneider, 1960) helps to bind peripheral regions and social groups more tightly to the central state. And as O'Donnell suggested in 1993, these effects are not unidirectional. Shrinking of the state due to economic crisis, defeat in war, or neoliberal reform can lead to disintegration of the national grid and erosion of state infrastructural power, and to the emergence of new or reinvigorated localisms. 


\section{c) Political and Strategic Perspectives}

A more explicitly political approach strives to underscore various ways and extents to which both colonial and contemporary rulers have used political territory and territorializing strategies strategically, in efforts to create political order in places and situations in which rulers do not take this for granted. ${ }^{5}$ Like the rulers of the Ottoman Empire, the USSR, and modern China, both colonial and postcolonial rulers in Africa have been pressured to view national territory as geopolitical space, and have employed the option that Sack (1984) calls "non-uniformity of territorial units" to promote the differential incorporation of territories into system-wide political systems and economies, and to layer, mold, containerize, and fragment constituencies, and to structure possibilities for conflict.

Viewed in this way, the extension of state infrastructural power is a political process. The pace and localization of this process is determined by factors related to geography, demography, and endowment, as flagged above, as well as by unevenness in the social topography of sub-national and localized communities and power structures. Within contexts so structured, the extension (and perhaps retrenchment) of state infrastructural power can often be understood as the product of negotiation and conflict between central and local actors.

In analyzing unevenness in state infrastructural power (or change over time), these perspectives generate three propositions. The first is that that political centralization itself (or the "built state") is itself a spatial and political outcome that calls for explanation, rather than a natural or default political arrangement. The second is that unevenness in the process of "national integration" is to be expected, and that both that integration and disintegration are possible. And thirdly, rulers can incorporate, not incorporate, or abandon regions, social groups, and functions strategically, as a function of their attempts to govern effectively and to hold onto power.

\section{FROM NATIONAL INTEGRATION TO OPEN ECONOMIES: TERRITORIAL AND SPATIAL EFFECTS}

These arguments about stateness and territorial politics resonate deeply in the historical experience of modern Africa. In many African countries, as in Latin America as viewed by O'Donnell in the early 1990s, market-oriented economic reform took place in a context of fiscal crisis and declining state capacity, and has been associated with a series of unintended and unexpected territorial effects. In Africa, the most dramatic manifestation at the national level is the resurgence of regional conflict, both inside and outside the electoral arena, and often with a heavily ethnic cast. At the subnational level, there is a resurgence of localisms and land conflict, often ethnicized, which fuels chronic tensions in regions and localities across a wide array of African countries. At the extreme, centrifugal forces have torn states into warring subnational entities or warlord- 
controlled fiefdoms. Côte d'Ivoire is one case in point, but the "disintegrating" effects of economic liberalization have been widely noted (Reno, 1998; 2011). The question here is why moves toward "open-economy" policies, which scale back interventionist state policies and increase the country's exposure to the world economy, have been associated with such dramatic spatial or territorial effects in so many sub-Saharan countries. ${ }^{6}$ The answers may provide some hypotheses for investigations of changing forms and degrees of stateness in Latin America.

Upsurges in regional conflict, ethnoregional conflict, and land-related conflict challenge the territorial cohesion of African states and political systems. Explanations for these phenomena that have been proposed in the African studies literature are not fully satisfying. One basic argument is that with the dwindling of central state revenues and spending, governments can no longer dispense the patronage that once served as the glue for nation-building. This explanation is largely correct, but it is underdetermining: it does not account for the geopolitical contours of the disintegration processes, or the territorial nature of the struggles that have emerged. Other analysts have suggested that market forces are inherently centrifugal, or that retreat of the state has unleashed previously repressed tribalisms and localisms. These analyses are also unsatisfying, because they can suggest that today's regionalisms and localisms are developing in institutional and historical voids, or that they spring up where state authority is erased or where it never really penetrated in the first place. This is manifestly not the case, for the stakes in today's territorial conflicts often involve struggles over how state power has been and should be used. Reintroduction of electoral politics, which has accompanied market opening in most cases, is also insufficient as an explanation for new political struggles over territory and jurisdiction. Heightened electoral competition does not, in itself, explain the territorial fault lines and stakes of political conflicts that often extend far beyond the electoral arena.

The discussion that follows treats this resurgent regionalism and these localisms as interrelated aspects of a new territorial politics. The new territorial politics centers on rearranging core-periphery relations, reordering political hierarchies among and within territorially defined constituencies, redefining the locus of control over resources and market access, and enforcing political authority and subnational citizenship rights within regions and localities. The main argument is that institutional or geopolitical legacies of the earlier, developmentalist era go far in defining the actors, playing field, and stakes in current rounds in the making and unmaking of African states. With the move to the open economy and the dismantling of earlier forms of state intervention in national economies in the 1990s, the institutional legacies of the 1940s-1980 state-building strategies became subversive of the forms of national integration they originally helped promote. ${ }^{7}$ Evidence of these institutional effects is found in the geography of today's

6 On the effects of trade openness on domestic politics and institutional development, see Leys (1996), Bates (1997) and Kurtz (2004). The term "open economy" refers to the effects of the economic policies of the neoliberal era, which is juxtaposed to an earlier era of statist economic management.

7 Bunce (1999) used the term "subversive institutions" to argue that the institutional design of state socialist regimes helps explain the rapid collapse of Soviet control in Eastern Europe from 1989-1992. 
conflicts: the new territorial politics follows fault lines and divisions that were carved into national bodies politic by the modern state itself.

This paper argues that four legacies of developmentalist-era state-building structure today's territorial politics. First is a legacy of competitive regional divisions that were institutionalized and managed by the developmentalist state. Second is the legacy of territorial administration and local political repression exercised through patchworks of local states with ethnicized constituencies, subnational citizenship rights, and ethnically defined entitlements. Third is intensely politicized land rights in the rural areas. And fourth, in many African countries, is incomplete consolidation of a national political class, leaving fractured ruling strata whose members have strong incentives to compete for advantage at the center, often at the expense of investing in strengthening the center. In national arenas so structured, economic liberalization, including the diminished distributive role of the central state, tends to produce a set of distinctive territorial effects: competition among the leaders of regionalized constituencies for control over the center; struggle over the local state; conflict over land rights and citizenship; and atrophy of the center. The new forms of territorial politics erode forms of national integration achieved in the earlier era. Prospects for maintaining and reproducing the centralized states that emerged from the 1950s through the 1980s, along with the forms of national and territorial integration that many were able to achieve, are compromised in the open-economy setting.

These points are developed below. The first part of the discussion describes territorial and geopolitical strategies that worked in many African countries to produce national integration in the era of state-led development, which came to a close in the mid-1980s. The second part describes forms of territorial politics that have been visible across much of Africa since the 1990s, in this new, open-economy era.

The analysis can be juxtaposed to alternative approaches to the study of the African state and government, especially to those that see power in Africa as essentially unstructured, non-institutionalized, and network-based or patrimonial. In these alternative approaches, state decay is attributed mostly to corruption, bad policy choices, and African rulers' refusal to state-build. The analysis here contributes to other recent works that emphasize institutionalization and unevenness in state-building trajectories. ${ }^{8}$ Here we follow North (1981), Grief (2006), Ostrom (2005) and others in the New Institutional Economics who take account of informal as well as formal institutions, and who emphasize the strategic logics that can drive the extension or retrenchment of the reach of the state.

\section{a) National Integration in the Era of Statist Developmentalism}

Development as it was pursued from the 1950s to the 1980s was a state-led task, the ostensible aim of which was building a national economy-that is, an integrated, interdependent economic system that functioned within the juridical boundaries of the territorial state. 
The ideal national economy was sectorally diversified, regionally balanced, and equipped with mechanisms to allow the state to appropriate and redistribute resources throughout the national space (Leys, 1996). Done right, this was supposed to accelerate economic growth, generate wealth that would finance the state itself and extend its regulatory reach, and generate employment opportunities and social services to benefit citizens. Economic development was expected to promote political and societal integration by reinforcing the political hegemony of the central government and by binding citizens in social contract to the state.

Key aspects of this project were explicitly territorial or geopolitical in nature. A national currency, capital controls, interest-rate controls, import and export controls, and exchangerate controls gave central states tools they used in the effort to manage the macroeconomy as an integrated system and to regulate the insertion of the national economy, conceived as an integrated unit, into world markets. A sine qua non of national economic planning and management was delimiting national boundaries, policing them, and controlling flows of goods, capital, and persons across boundaries.

Within the national economy, statist economic policies worked to centralize control over resource flows and access to money-making opportunities, and thus to shape patterns of wealth accumulation. As has been noted extensively in the literature on African political economy, these processes promoted the accumulation of power at the center of the political system (and also shaped patterns of class formation). Centralization is a spatial effect. Less systematically tracked is the wide array of distinctively spatial or territorial aspects of these processes. Most obvious, perhaps, was that statist controls allowed central rulers to structure the interregional redistribution of resources, which was an explicit part of the development agenda. The formal goal was to promote "balanced regional development" which would, in turn, promote political integration of the national unit because politically contentious regional disparities could be reduced, and disadvantaged regions could be rewarded for cooperating with central rulers. ${ }^{9}$

Sectoral policies provided tools for allocating resources throughout the national space and structuring the spatial locus of accumulation. Nationalized banking systems, political allocation of credit, and government investment in infrastructure and productive activities directed capital and cash not only to particular firms, individuals, and clans, but also to particular regions and localities. These same processes worked to impede the accumulation of capital in places disfavored by central rulers. Rural development policies were almost always targeted at specific geographic areas. Export-crop marketing boards were a particularly powerful tool for structuring the accumulation and distribution of wealth. Marketing boards apportioned export earnings among public and private agents at all levels of the circuit. At the same time, they defined hierarchical orderings of localities, towns, and regional centers in export-producing regions and gave central state agents the means to mediate and control accumulation at sites along the marketing chain. In Senegal, central rulers allowed wealth extracted from export-crop producers to pool 
in provincial cities that were the political fiefdoms of powerful regime barons. In Côte $\mathrm{d}$ 'Ivoire, central authorities made sure that all proceeds of export-crop production ended up at the center, to be doled out by the Head of State himself to his relatives and political favorites. In most African countries, extension of transportation and communications infrastructure accentuated the "core and periphery" structure of the national political economy. Regions and secondary cities were tied more tightly to the center, and the primacy of the center was enhanced.

The role of land tenure law as an instrument of territorial and spatial control has been largely overlooked in literatures that have focused on national-level political economy in Africa. In sweeping affirmations of colonial rulers' claims to complete dominion over the African territories, postcolonial regimes claimed (in the name of the state) property rights over most African countries' basic resource: rural land. Legally, then, African peasants have never been freeholders. As Liz Alden Wily (2001) argues, the state is their landlord, or overlord. This means that across most of rural Africa the most basic institution of a market society -private property in the means of production-does not exist, and central state agents exercise direct or indirect political control over access to livelihoods for the vast majority of the population. In ways that are sanctioned and officially institutionalized by the central state, most people obtain access to land as members in localized, ethnicized communities. Relationships that provide access to productive resources remain highly localized, thus reinforcing localized (and ethnicized) political controls over rural citizens while limiting the mobility of farmers and capital within the national space. In some areas, rural development policies provided a downward trickle of resources that helped stabilize these localized and geographically specific patronclient relationships.

Elaboration of administrative apparatuses that were national in scope created the political framework for "national integration" and for building the national economy. Territorial administration gave the central state an on-the-ground presence and the administrative capacity to carry out local spending projects, social service delivery, market monitoring and regulation, and land tenure policy. To this end, rulers modified, extended, and often tightened the grids of territorial administration that they inherited from the colonial state. This process (1) divided the "national" population into groups and subgroups subject to the administrative jurisdiction of different field agents of the center, as Mamdani (1996) has argued, (2) defined units of political representation, and (3) defined the territorial scope and boundaries of the political playing field at local and regional levels. The extent and manner of top-down control varied considerably across space, reflecting highly uneven population distributions, the uneven development of commercial agriculture and other economic activities, and differences in local social and political configurations (Herbst, 2000; Boone, 2003b).

The political stakes in the demarcation of subnational territorial jurisdictions were high. Rulers mapped out territories and constituencies in ways that would help shore up and gather power at the center, strengthen local allies, and weaken local opponents. Kwame Nkrumah, for example, split the powerful Ashanti Region in two (creating the new regional jurisdiction of Brong-Ahafo) in order to weaken his Asante political 
opponents and institutionalize the power bases of his allies in the Brong area. Territorial administration created officially recognized building blocks of "the nation", countrywide political coalitions, and the national economy.

The politics of regional conflict and competition, highly salient and visible in the 1950s, seemed to wind down in the 1960s and 1970s and to yield to the extreme, overbearing primacy of the center. Regional conflicts in the 1950s in countries like Ghana, Uganda, Congo, Nigeria, Kenya, and Côte d'Ivoire were battles over redistribution; the protagonists assumed that development and "nation building" would be funded by taxing the most successful export-producing farmers or mineral-rich regions. In the 1960s and 1970s, however, international borrowing and state entrepreneurialism emerged as alternatives to the transfer of resources from big exporting regions to the center and to poorer regions. External inflows and the expanding pie made it possible for central rulers to engage in distributive politics while dodging some of the political costs and risks of social conflict that are associated with direct taxation and redistribution.

Statist economic policies provided central rulers with resources, institutional infrastructure, and opportunities they used to create territory wide political coalitions managed by the center, whose leading members had vested interests in the survival of the national state as an organization and a territorial entity. Post independence leaders of one-party states from Zambia and Kenya, and from to Senegal and Cameroon, were able to engineer what Bayart (1989) calls "fusion of elites" -that is, the rise of a national-level political class drawn from the heterogeneous social, geographic, and functional units that were contained with the national space.

In the mid-1980s, failure of economic strategies that had been in place since the 1950s to produce sustained growth, as well as severe and chronic fiscal and trade deficits within African countries and unfavorable changes in world markets (including oil price hikes, interest rate hikes, and declining terms of trade for most Africa export commodities), precipitated Africa's debt crisis. Dependence on continued inflows from the international financial institutions (IFIs) pressured African governments to go along with ambitious Structural Adjustment Programs (SAPs) which were designed to scale back state intervention in the economy, give freer play to market forces within the domestic arena, and increase African countries' exposure to international market forces. Following Bates (1997), Kurtz (2004), and others, we call the changes wrought by the fiscal crisis of the state, and by the implementation of these reform packages, the "transition to the open economy".

This process diminished the capacity of central rulers to regulate the insertion of the national economy into world markets, govern domestic markets, and govern domestic flows of capital, other productive inputs, and commodities-indeed, those were central purposes of policy reforms aimed at economic liberalization. As many analysts have argued, "retreat of the state" diminished the capacity of African rulers to dispense political patronage, and thus it destabilized old ruling coalitions and modes of governing. ${ }^{10}$ 
Transitions toward the open economy have been attended by a series of distinctive geopolitical or territorial effects. Liberalizing policy reforms have meant the dismantling of mechanisms that central rulers had used to centralize the appropriation of surpluses and revenues from agriculture, trade, and industry. Gone are the agricultural marketing boards, much of the state-owned enterprise sector, the state monopolies over the banking sector, and the state's import and export monopolies. These were the mechanisms that had enabled central rulers to distribute resources and investment throughout the national space and to control resource flows in ways that gave the state a local presence, tied regions and local constituencies to the center, governed the course of local politics, enhanced the primacy of the center, and mediated relations among regional constituencies. As Colin Leys argues (1996), the state-led project of building an integrated national economy is largely a thing of the past. With it went many of the neomercantilist tools and strategies that central rulers had used to pursue the national integration project in the earlier period (Boone, 1993; Bayart et al., 1999: xvii).

For much of Africa, shifts to the open economy have coincided with moves toward political liberalization. In many countries, this means that competition for access to state power is now played out in an electoral arena that is itself structured by geopolitical legacies of the past.

\section{b) National Disintegration and the Open Economy}

Retreat of the state in the late 1980s and 1990s destabilized many of the old state-made or state-enforced controls over space, property, and resources. Economic liberalization also deprived regimes of economic monopolies that central rulers had employed to manage interregional, regional, and local politics. The shift toward the open economy opened up new competition for control over the central state, contests to redistribute power among regions within the national space, and competition to reconstitute authority relations, property rights, and markets at the regional and local levels.

This is the new territorial politics. It does not take place in an institutional or geopolitical void. On the contrary, it is structured by inheritances of the earlier state-building and nation-building period.

\section{i. The New Regionalism}

The first legacy of statist developmentalism is competitive regional divisions, which were institutionalized and managed by central rulers in the era of authoritarian politics. In the open-economy setting, these divisions have become the fault lines of the new regionalism.

In most African countries, an ethnic political grid was institutionalized in the structures of territorial administration and in the politics of incorporation and representation at the national level. This kind of state- and nation-building created ethnicized regional constituencies. In many countries, it nurtured the rise of a national-level elite of ethnic brokers who mediated the downward flow of state resources to their constituencies. 
"Ethnic arithmetic" structured a kind of power sharing among regions and divvied up positions within the national elite. With the shrinking of the distributive capacity of the central state, erosion of its capacity to intervene in provincial political economies, and diminution of central rulers' ability to discipline factions of the national elite, the ethnic arithmetic of the earlier era is often proving to be subversive of the national unity it originally helped promote. This sets the stage for heightened competition for control within the regions, as well as heightened competition among regional factions for control over the center. ${ }^{11}$

Liberalization and deregulation of the economy may lead to the erosion of the patronclient relations that tied regional bosses to the central regime, but opening of the economy does not necessarily erode the importance of patron-client relations that structure the political economy at the regional and local levels. Because of the limited scope and depth of markets, and because of weak commodification of factors of production in the rural economy, provincial political leaders (and new political entrepreneurs) can mobilize resources and exercise forms of political authority that do not depend upon handouts from the central state. Establishing control over resource flows can provide a foundation for mobilizing power in decentered, regionalized political economies, as William Reno (1999) has argued in an analysis of warlordism in sub-Saharan Africa. Even the ability to broker access to markets (or financial transactions, storage facilities, inputs, etc.) can be parlayed into political influence and clout. De facto or de jure liberalization, and the move to an open-economy setting, can unleash new contests to establish control over resources and resource flows in the localities and regions. Power gained at the subnational level can then be parlayed into political capital that is invested in competition-either electoral or otherwise-for influence and power in the national political arena.

\section{ii. Heightened Salience of the Local State}

A second institutional legacy of developmentalism was the consolidation of local states. Along with this came the consolidation of subnational citizenship rights, identities, and entitlements. The "decentralized despotism" described by Mamdani (1996) was exerted through a mosaic of local states, or local political orders, many of them centered on some kind of neotraditional ruler. Local leaders could draw on their role as brokers of the downward flow of state resources, as well as upon other forms of authority or legitimacy (lineage, religion, customary land-allocation prerogatives) in order to anchor their power in the villages and localities. Central rulers manipulated and institutionalized these arrangements in efforts to control rural populations and anchor the authority of the modern state.

Economic liberalization and cutbacks in the size and spending power of central government have shrunk the territorial reach of the center. Center-periphery linkages centered on export-oriented agriculture weaken as marketing systems are deregulated and as rural

11 The editors' introduction to Berman, Eyoh, and Kymlicka (2004, p.9) identifies the current "regionalization of political competition" in Africa as "strikingly reminiscent of politics at the terminal phase of colonialism". 
development programs that were based on the top-down flow of agricultural inputs are abandoned. Outside the more economically favored regions, fiscally strapped national governments can no longer provide the jobs and social services that helped give the central state a local presence and bolstered the distributive powers of local elites.

Neoliberal reformers hoped that the weakening of central control over the economy would broaden and deepen markets in provincial economies and empower marketbased social actors. Yet in many parts of Africa today, the open economy appears to have reinforced the salience of the local state. This is partly because cutbacks in central spending and administration, often coupled with formal decentralization initiatives, have pushed the burdens of local administration, social service provision, and dispute adjudication onto local, often nonstate, political authorities. Yet the enduring and even heightened salience of local authorities and authority structures also reflects the fact that localized authority relations continue to structure resource allocation and market access in powerful ways. Under these conditions, retreat of the central state does not necessarily depoliticize resource access; instead, it can produce a downward shift in the geographic locus of control over resource flows. Shifts to the open economy can liberate some local resources or resource flows from central control (cross-border flows, for example), creating new stakes and new dynamics in the politics of resource capture and resource allocation at the local level.

\section{iii. The Land Card}

A third legacy of the earlier state-building era is the intense politicization of land rights. Shifts to the open economy can work in several ways to raise the stakes of land politics and stoke land-related political tensions, as observed in the 1990s in places like Rwanda, Kenya, the Senegal River Valley, and Côte d'Ivoire. ${ }^{12}$

Open economy dynamics can contribute to bottom-up pressures for defense of, or revisions of, land rights. Open economics has increased the volatility of farm-gate prices for many cash crops, aggravating pressures caused by downward trends in world market prices for Africa's main export crops. Reductions in the use of fertilizers and pesticides that were once subsidized and/or supplied by governments, along with soil degradation, can decrease productivity and give farmers incentives to practice more extensive forms of agriculture. Unemployment and economic recession in the urban areas can lead to a drying-up of remittance flows that helped sustain rural households in the earlier era; it may also add to demographic stress in farming districts by producing a reverse flow of migrants (returnees) to the provinces. At the same time, currency devaluations, changing trade patterns, and road building can create new markets and new opportunities that can also contribute to rising land values and new challenges to existing land-use patterns.

These changes can increase demand for farmland, intensify economic stress on rural communities and households, generate pressure for the redistribution of land rights, 
and inflame land tenure conflicts. ${ }^{13}$ Where land is not fully commoditized, redistribution necessarily involves the use of political power to reallocate land among various categories of claimants. Subnational citizenship can be invoked to claim land rights that trump those of "strangers" or newcomers who are not indigenous to the locality.

A problem of the neoliberal era is that there is also a strong top-down logic to reactivating land politics as a high-visibility public issue. The capacity of political authorities at the central and local levels to deliver social services, subsidized inputs, stable or higher producer prices, off-farm jobs, and other tangible benefits to their prime rural constituencies has diminished. Yet state actors can still deliver and enforce rural property rights; this constitutes one of the most important remaining connections between central rulers and rural populations. Property rights adjudication also remains a prime function of the local state, as well as a vital material and moral link between neotraditional leaders and their constituencies.

Both central rulers and regional leaders thus have heightened incentives to use land tenure policy as a mechanism to activate or reinforce rural constituencies. Playing the land card can appear as an effective electoral strategy in a postdevelopmentalist era, when social pressures are high and rulers have few other material benefits to deploy in the quest for partisan advantage.

\section{iv. Atrophy of the Center?}

For some African countries, the fourth inheritance of the earlier era of state-building is a weakly integrated political class. The open-economy order changes relations among the constituent elements of the political class and pressures political brokers to find new strategies to reproduce and defend their political power. Deregulation, privatization, and the opening of national borders deprive central rulers of the economic monopolies needed to mediate accession to the political class, manage competition within it, or moderate opportunistic and predatory behavior. ${ }^{14}$ If the national political elite disintegrates into regional factions competing for control over the center (and thus over the power to affect interregional resource transfers in favor of their constituencies), there may be no one left to defend and advance "the national interest". In extreme cases, the central state itself may fall victim to a kind of tragedy of the commons. If there is no neutral, superordinate, or third party to enforce political deals, power sharing among political leaders becomes hard to achieve. National states formed in the earlier era are at risk of atrophy.

\section{CONCLUSION}

African experiences underscore the inherent historicity and contingency of state-building processes, and many possible forms and causes of unevenness and decline (or growth) 
in "stateness". Both political strategy and broader macropolitical and macroeconomic circumstances shape the course of state-making. Levels and quality of stateness vary over time, across regions, across functional domains of state action (eg. market regulation, social service provision), and across social groups (which may be defined by race, ethnicity, class, region, gender, or combinations thereof).

Viewing state capacity in this way is an argument against two tendencies that are latent or implicit in some attempts to operationalize Mann's concept of "state infrastructural capacity" as a metric for cross-regional and cross-national comparison. The first is the tendency or analytic convenience of measuring stateness or state capacity against a hypothetical global standard of "blue areas" or national-level scores for "OECD democracies". The second is the assumption that the primary goal of rulers anywhere is to project state capacity evenly across social groups and across the national territory.

It seems reasonable to maintain, as a working hypothesis, that no state-builders would, in the absence of very strong societal pressure to do otherwise, opt to spread state capacity evenly across the national territory in the presence of geographically uneven distributions of population, economic activity, challenging topography, political support for the regime, and/or political resistance or opposition to the state or regime. This hypotheses finds support in the Côte d'Ivoire story, where rulers concentrated state-building efforts in regions of high economic activity and potential opposition, neglecting other parts of the national space. This strategic approach worked well for the first 30 years of Côte d'Ivoire's post colonial history, when it registered as one of Africa's strongest (most efficiently-administered) and economically successful states. The hypothesis also finds support in the African state of Rwanda, both before and after the 1994 state-led genocide, where we see a contrasting pattern of much more evenness in the territorial reach of the state. In Rwanda, a small, compact country with high population densities and commercial agricultural production spread throughout most of the national space, a strong state achieved exerted high "infrastructural power" (power to tax, monitor, mobilize, administer the population, suppress crime, repress potential opponents, etc.) that reached deep into micro-localities, including neighborhood cells, throughout the national territory. A explanatory logic that stresses leaders' strategic decision-making in response to economic, demographic, and political opportunities and challenges would also help account for the notoriously uneven patterns in levels and quality of social-service provision in the United States, where social groups without political clout are often found in marginal and marginalized territorial jurisdictions (such as in the northeastern inner-cities, and the rural backwaters of the south and west), where the infrastructural power of the state, measured by state provision of social services and local public security, has historically much lower than it is in wealthy areas that exercise both political autonomy and political clout.

The empirical unevenness in stateness in LAC countries that $\mathrm{O}^{\prime}$ Donnell identified in his much-cited 1993 essay on this topic is surely an intrinsic feature of state and stateness in this region, not merely a result of the neoliberal economic policies and "state shrinking" that he foregrounded in that article. And as he acknowledged, it would hold 
not only for the urban-rural and cross-regional disparities that have been emphasized in this paper, but also for unevenness in the reach of the state in urban areas (in terms of security provision, social service delivery, and extractive capacity), where stateness varies along spatial and class lines in ways that have been documented by several of the contributors to this collection.

That said, the analysis above also underscores the fact that strategic state-builders will attempt to adapt and respond to economic constraints, which necessarily change over time. The argument that most rulers will be pressured to expand or contract the reach of the state in response to the loosening and tightening of fiscal constraints (which may well reflect expansion and contraction of the economy at large, as may happen as a result of changes in the international political economic setting) seems like a good working hypothesis, and it is a point of departure for many of the contributors to this collection. In sub-Saharan Africa, rulers responded to fiscal crisis of the state, economic recession, and the neoliberal reforms of the late 1980s and 1990s by reorienting governing strategies away from the penetrative, state-building and nation-building strategies of the 1950s-1970s and toward state retrenchment, cut-backs in social services, privatization or shuttering of state enterprises, divestment in economic infrastructure like roads and bridges. "Stateness" declined by force of circumstances and by design. The political counterpart was often exclusion, peripherialization, and marginalization of those citizens who were no longer provided with state-financed and -managed social services, economic infrastructure, or public security in the form of policing, etc. This process was uneven -islands or regions of pretty good state provision persisted- as a political and strategic analysis of state retrenchment would suggest. The Côte d'Ivoire case is one example, but similar patterns are observable in the Central America, the Andean countries, and Haiti (as described by Eaton, Feldmann, and Baranyi in this volume), as well as in many, perhaps most, other Latin American and Caribbean countries.

Such arguments may also provide some leverage in describing and explaining the emergence of neo-statist projects in some African countries in the last decade. Ethiopia and Rwanda have undertaken to strengthen the state, rebuild or extend the territorial reach of the state (albeit strategically), and rebuild and extend economic infrastructure, often explicitly rejecting the "less state, better state" mantra of the 1980s and 1990s and resisting pressure to move toward competitive democracy in the 1990s and 2000s. Uganda and Angola have also done so, although more unevenly and arguably with less success. The attributes that differentiate these states from many others in sub-Saharan Africa are telling. These are ex-military regimes that (a.) have an organizational core that is rooted in the corporatist institutions of the military, (b.) have embraced technocratic, authoritarian governing styles and techniques, (c.) and have robust sources of state financing that are under rulers' sovereign control (the salience of which is underscored by Baranyi in this volume). The uneven spread of these attributes across these four countries and over time helps to explain variation in the quality and success of their neo-statist projects. Each has manipulated territory and geopolitical dynamics in a ruthless politics state-building, and all four have been more successful at such geopolitics than their counterparts in Sudan 
and the DRC. In these African examples of more or less successful neostatism, higher stateness comes with authoritarian rule. This serves as a cautionary note for studies that inadvertently suggest that "stateness" per se is an unmitigated good.

\section{REFERENCES}

Alesina, Alberto and Enrico Spolaore. 2003. The Size of Nations. Cambridge, MA: MIT Press.

Amanor, Kojo Sebastian. 1999. Global Restructuring and Land Rights in Ghana: Forest Food Chains, Timber, and Rural Livelihoods. Uppsala: Nordiska Afrikainstitutet Research Report \#108.

André, Catherine and Jean-Philippe Platteau. 1998. “Land Relations under Unbearable Stress: Rwanda Caught in the Malthusian Trap". J. of Economic Behavior and Organization 34 (1): 1-47.

Azam, Jean-Paul. 2001. "The Redistributive State and Conflict in Africa". J. of Peace Research 38 (4): 429-444.

Bakary, Tessy D. 1986. "Côte d'Ivoire: une 'décentralisation politique centralisée". Géopolitique Africaine 2 (juin): 205-230 and (octobre): 65-104.

Barkey, Karen. 2008. Empire of Difference: The Ottomans in Comparative Perspective. Cambridge and New York: Cambridge University Press.

Bates, Robert H. 1981. Markets and States in Tropical Africa. Los Angeles and Berkeley: University of California Press.

Bates, Robert H. 1997. Open-Economy Politics. Princeton: Princeton University Press.

Bayart, J-F. 1989. L'Etat en Afrique. Paris: Fayard.

Bayart, Jean-François, Stephen Ellis and Béatrice Hibou. 1999. The Criminalization of the State in Africa. Oxford and Bloomington, IN: James Currey and Indiana University Press.

Berman, Bruce, Dickson Eyoh and Will Kymlicka, eds. 2004. Ethnicity and Democracy in Africa. Oxford and Athens: James Currey and Ohio University Press.

Berry, Sara. 2002. "Debating the land question in Africa". Comparative Studies in Society and History 44 (4): 638-68.

Boone, Catherine. 2003a. "Decentralization as Political Strategy in West Africa". Comparative Political Studies 36 (4 [May]): 355-380.

Boone, C. 2003b. Political Topographies of the African State: Rural Authority and Institutional Choice. New York and Cambridge: Cambridge Univ. Press.

Boone, C. 2007a. "Africa's New Territorial Politics: Regionalism and the Open Economy in Côte d'Ivoire". African Studies Review 50 (1 [April]): 59-81.

Boone, Catherine. 2007b. "Property and Constitutional Order: Land Tenure Reform and the Future of the African State". African Affairs 106 (Oct.): 557-586.

Boone, C. 2011. "Politically-Allocated Land Rights and the Geography of Electoral Violence in Kenya". Comparative Political Studies 44 (10 [October]): 1311-1342.

Boone, C. forthcoming. Property and Political Order in Africa: Land Tenure, Land Conflict, and the State. NY: Cambridge University Press.

Branch, Daniel and Nicholas Cheeseman. 2006. "The Politics of Control in Kenya: Understanding the Bureaucratic Executive State, 1952-78". Review of African Political Economy 107: 11-31.

Bunce, Valerie. 1999. Subversive Institutions: The Design and Destruction of Socialism and the State. Cambridge: Cambridge University Press.

Caramani, Daniele. 2004. The Nationalization of Politics: The Formation of National Electorates and Party Systems in Western Europe. Cambridge and New York: Cambridge University Press.

Chauveau, Jean-Pierre. 2000. "Question foncière et construction nationale en Côte d'Ivoire". Politique Africaine 78 (2000): 94-125.

Chhibber, Pradeep and Ken Kollman. 2005. The Formation of National Party Systems: Federalism and Party Competition in Canada, Great Britain, India, and the United States. Princeton: Princeton University Press.

Gazibo, Mamoudou and Daniel C. Bach. 2012. "Introduction". In The Neopatrimonial State in Africa and Beyond. Gazibo and Bach, eds., 1-6. London: Routledge. 
Gibson, Edward. 2005. "Boundary Control: Subnational Authoritarianism in Democratic Countries". World Politics 58 (1 [October]): 101-132.

Goheen, Mitzi. 1992. "Chiefs, Sub-Chiefs, and Local Control", Africa: Journal of the International African Institute, 62 (3): 389-411.

Green, Elliott. 2012. forthcoming. "On the Size and Shape of African States". International Studies Quarterly. Greene, Kenneth F. 2007. Why Dominant Parties Lose: Mexico's Democratization in Comparative Perspective. Cambridge: Cambridge University Press.

Greif, Avner. 2006. Institutions and the Path to the Modern Economy. Cambridge: Cambridge University Press.

Gyimah-Boadi, E. and Cyril Daddieh. 1999. “Economic Reform and Political Liberalization in Ghana and Côte d'Ivoire: A Preliminary Assessment of Implications for Nation-Building". In State Building and Democratization in Africa, ed. Kidane Mengisteab and Cyril Daddieh, 125-156. Westport, CT.: Praeger.

Hechter, Michael. 2008. Containing Natinoalism. Oxford: Oxford University Press.

Herbst, Jeffrey. 2000. States and Power in Africa. Princeton: Princeton University Press.

Kahl, Colin. 2006. States, Scarcity, and Civil Strife in the Developing World. Princeton: Princeton University Press.

Kurtz, Marcus. 2004. "Dilemmas of Democracy in the Open Economy: Lessons from Latin America". World Politics 56 (2):262-302.

Leys, Colin. 1996. The Rise and Fall of Development Theory. London and Bloomington: James Currey Ltd. and Indiana University Press.

Lipset, S. M. \& Rokkan, S. 1967. "Cleavage structures, party systems, and voter alignments: an introduction". In S.M. Lipset \& S. Rokkan (eds.), Party systems and voter alignments: crossnational perspectives. New York: Free Press.

Mamdani, Mahmood. 1996. Citizen and Subject: Contemporary Africa and the Legacy of Late Colonialism. Princeton: Princeton University Press.

Nord, Philip. 2000. "Introduction". In Nancy Bermeo and Philip Nord, eds., Civil Society before Democracy: Lessons from Nineteenth-Century Europe, xiii-xxxiii. London: Rowman and Littlefield Publishers, Ltd.

North, Douglass. 1981. Structure and Change in Economic History. New York: W.W. Norton.

Nugent, Paul. 2010. "States and Social Contracts in Africa". New Left Review 63 (May-June): 35-63.

O'Donnell, Guillermo. 1993. "On the State, Development, and some Conceptual Problems: A Latin American View with Some Glances at some Post-Communist Countries". World Development 21: 1355-1369.

Ostrom, Elinor. 2005. Understanding Institutional Diversity. Princeton, NJ: Princeton University Press.

Peters, Pauline. 2004. "Inequality and Social Conflict over Land in Africa". Journal of Agrarian Change, 4 (3): 269-314.

Pitcher, Anne, Mary H. Moran and Michael Johnson. 2009. "Rethinking Patrimonialism and Neopatrimonialism in Africa". African Studies Review 52 (1) [April]): 125-156.

Reno, William. 1998. Warlord Politics and African States. Boulder: Lynne Rienner Press.

Reno, William. 2011. Warfare in Independent Africa. Cambridge University Press.

Roth, Dik. 2003. "Ambition, Regulation, and Reality: Complex Use of Land and Water Resources in Luwu, South Sulawesi, Indonesia". Ph.D. dissertation, Wageninen University, 14 November.

Sack, Robert David. 1986. Human Territoriality: Its Theory and History. Cambridge: Cambridge University Press.

Schattschneider, E.E. 1960. The Semisovereign People: A Realist's View of Democracy in America. New York: Holt, Reinhart and Winston.

Sindzingre, Alice. 2000. "Le contexte économique et social du changement politique en Côte d'Ivoire". Afrique Contemporaine 193: 27-37.

Shivji, Issa. 2006. Let the People Speak: Tanzania Down the Road to Neo-Liberalism. Dakar, Council for the Development of Social Science Research in Africa: CODESRIA Books.

Skrowneck, Stephen. 1982. Building a New American State: The Expansion of National Administrative Capacities, 1877-1920. Cambridge: Cambridge University Press. 
Toulmin, Camilla and Julian Quan, eds. 2000. Evolving Land Rights, Policy and Tenure in Africa. London: United Kingdom Department for International Development, International Institute for Environment and Development, Natural Resources Institute (DFID/IIED/NRI).

Wily, Liz Alden. 2001. "Reconstructing the African Commons". Africa Today 48 (1): 77-99.

Woods, Dwayne. 1989. “Ethno-regional Demands, Symbolic and Redistributive Politics: Sugar Complexes in the North of the Ivory Coast". Ethnic and Racial Studies 12 (4): 469-489.

Woods, Dwayne. 2004. "Predatory Elites, Rents and Cocoa: A Comparative Analysis of Ghana and Ivory Coast. Commonwealth and Comparative Politics 42 (2):224-241.

Catherine Boone is Professor of Government and Fellow of the Long Chair in Democratic Studies at the University of Texas at Austin. She received a Ph.D in Political Science from MIT and is author of Political Topographies of the African State (Cambridge, 2003) and Property Rights and Political Order: Land Rights and the Structure of Politics in Africa (Cambridge, forthcoming). She is interested in political economy and political geography.

Email: cboone@austin.utexas.edu 
